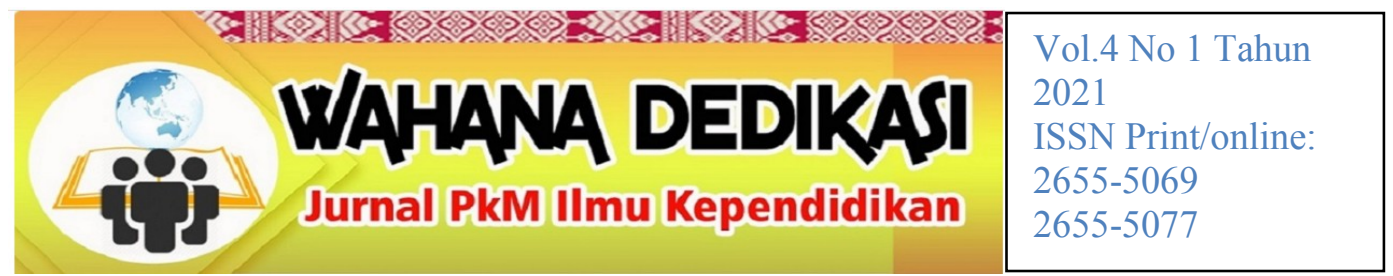

\title{
IMPLEMENTASI PEMBELAJARAN KEWIRAUSAHAAN DI MASA NEW NORMAL
}

\author{
Januardi ${ }^{1}$, Diana Widhi Rachmawati ${ }^{2}$, Neta Dian Lestari ${ }^{3}, \mathbf{H j}$. Masnunah ${ }^{4}$, \\ Candra Kurniawan ${ }^{5}$, Nova Pratiwi ${ }^{6}$ dan Hendri Gunawan ${ }^{7}$ \\ Universitas PGRI Palembang ${ }^{1,2,3,4,5,6,7}$ \\ dianawidhi72@gmail.com
}

\begin{abstract}
Abstrak
Perkembangan dan perkembangan di bidang teknologi informasi, khususnya internet, mengganggu arus informasi dan, seiring waktu, perspektif spiritual, birokrasi, organisasi. Program tidak hanya mengukur pembuatan data di Internet, informasi ditransmisikan meskipun sangat tinggi, sains tidak berguna. Protokol tersebut diyakini dapat mengajarkan budaya pendidikan dan pelatihan. Perkembangan dan kemajuan teknologi sudah menjadi sangat populer, sehingga penggunaan audio tutorial, alat peraga dan sekolah beradaptasi dengan era new Normal. Oleh karena itu judul PkM yaitu: "Implementasi Pembelajaran Kewirausahaan di Masa New Normal" sebagai bentuk pelaksanaan Tri Darma Perguruan Tinggi, berupa Pengabdian kepada Masyarakat (PkM). PKM ini diikuti 10 guru dan 30 siswa di SMK N 1 Pagaralam.
\end{abstract}

Kata kunci: Pembelajaran Kewirausahaan, Teknologi, Siswa

\begin{abstract}
Developments and developments in the field of information technology, particularly the internet, disrupt the flow of information and, over time, spiritual, bureaucratic, organizational perspectives. Programs not only measure the creation of data on the Internet, information is transmitted even though it is very high, science is useless. The protocol is believed to be able to teach a culture of education and training. Technological developments and advances have become very popular, so that the use of audio tutorials, teaching aids and schools has adapted to the new Normal era. Therefore, the title of PkM is: "Implementation of Entrepreneurship Learning in the New Normal Period" as a form of implementation of the Tri Dharma of Higher Education, in the form of Community Service (PkM). This PKM was attended by 10 teachers and 30 students at SMK N 1 Pagaralam
\end{abstract}

Keywords: Enterpreneurship Learning, Technology, Student

Artikel disetujui tanggal:18-02-2021

Corresponden Author:Diana Widhi Rachmawati, e-mail:_dianawidhi72@gmail.com

DOI: http://dx.doi.org/10.31851/dedikasi.v4i1.5233 do] 


\section{WAHANA DEDIKASI}

\section{PENDAHULUAN}

Dunia tengah dilanda pandemi virus covid-19 saat ini, kita semua harus bahu membahu saling perduli dan mengikuti anjuran pemerintah untuk memutus mata rantai pandemi ini dengan cara hidup bersih cuci tangan dengan sabun dan air mengalir, memakai masker saat keluar rumah, jaga jarak, berdiam diri dirumah saja dan jangan menyentuh muka sebelum memcuci tangan. Pertempuran yang paling besar itu adalah ketidak perdulian terhadap diri sendiri, keluarga dan orang lain, setiap orang harus sadar akan bahanya pandemi virus covid 19 ini. Secara jujur bila merasakan gejala virus corona segera berobat dan mengisolasi diri agar tidak menyebar dan menulari orang lain.

\section{World Health Organization} (WHO) COVID-19 adalah penyakit menular yang disebabkan oleh virus corona yang baru ditemukan. Sebagian besar orang yang terinfeksi virus COVID-19 akan mengalami penyakit pernafasan ringan hingga sedang dan sembuh tanpa memerlukan memerlukan perawatan khusus. Orang lanjut usia (lansia) yang berusia di atas 60 tahun dan yang memiliki masalah medis mendasar seperti penyakit kardiovaskular, diabetes, penyakit pernafasan kronis, dan kanker, memiliki risiko lebih tinggi terkena penyakit parah hingga kematian (Aprianto et al, 2021).

Oleh karena itu seorang pengajar harus memliki kemampuan pada teknologi komputer dan kemampuan mencari data melalui internet (Putra et al, 2020). Dengan dikembangkannya tutorial ini, maka layak pembelajaran bahwa guru harus mempelajarinya agar dapat memperlancar proses belajar mengajar, sehingga memudahkan proses pembelajaran agar berjalan dengan baik di kelas. Ada berbagai jenis media yang digunakan guru, seperti media visual, audiovisual dan media pembelajaran lainnya. Dengan pemanfaatan media tersebut, guru dituntut mampu mengembangkan media pendidikan yang kreatif dan 


\section{W/AHANA DEDIKASI}

inovatif khususnya di bidang kewirausahaan.

Implementasi merupakan suatu proses penerapan ide, konsep, kebijakan, atau inovasi dalam bentuk tindakan praktis sehingga memberikan dampak, baik berupa perubahan pengetahuan, keterampilan, maupun nilai dan sikap (Hamalik, 2007: 237). Pembelajaran kewirausahaan menurut Anita (2014: 12) adalah Proses pengintegrasian nilai-nilai kewirausahaan kedalam pembelajaran sehingga hasilnya diperoleh kesadaran akan pentingnya nilai-nilai, karakter wirusaha dan pembiasaan ke dalam tingkah laku peserta didik sehari-hari melalui proses pembelajaran baik yang berlangsung di dalam maupun diluar kelas.

Beranjak dari latar belakang di atas, dosen Fakultas Keguruan dan Ilmu Pendidikan Universitas PGRI Palembang oleh karena itu akan mengadakan kegiatan dengan tema

"Implementasi

Pembelajaran

Kewirausahaan Dimasa New

Normal” sebagai bentuk pelaksanaan
Tri Darma Perguruan Tinggi, berupa Pengabdian kepada Masyarakat (PkM).

\section{BAHAN DAN METODE}

Metode pelaksanaan kegiatan PKM ini yaitu; Pemberian materi dengan ceramah dan dan Tanya jawab melakukan pembekalan pembelajaran kewirausahaan yang kreatif secara langsung.

Evaluasi program merupakan suatu proses, yang secara eksplisit evaluasi mengacu pada pencapaian tujuan sedangkan secara implisit evaluasi harus membandingkan apa yang telah dicapai dari program dengan apa yang seharusnya dicapai berdasarkan kriteria yang telah ditetapkan. Pada konteks pelaksanan program PKM, kriteria yang dimaksud adalah kriteria keberhasilan pelaksanaan dan hal yang dinilai adalah hasil atau prosesnya itu sendiri dalam rangka pengambilan keputusan. Adapun criteria keberhasilan pelaksanaan kegiatan PKM ini adalah Minimal 60\% guru memahami tentang 


\section{WAHANA DEDIKASI}

implementasi

pembelajaran

kewirausahaan dan minimal 70\% siswa yang mengikuti PKM ini dapat menerapkannya dalam kehidupan sehari- hari-hari. Kegiatan Pengabdian kepada Masyarakat (PkM) ini dilaksanakan pada Hari Senin, 13 Desember 2020, Pukul 09.00 s/d 12.00 wib, secara langsung di SMK Negeri 1 Pagaralam

\section{HASIL DAN PEMBAHASAN}

Kegiatan pengabdian kepada masyarakat yang dilakukan oleh Lima dosen program studi Pendidikan Akuntansi di Fakultas Keguruan dan Ilmu Pendidikan di Universitas PGRI Palembang ini telah terlaksana dengan baik dan selesai sebagaimana waktu yang telah ditentukan. Rangkaian acara kegiatan ini dimulai dari salah satu dosen melakukan pembukaan dan pengantar serta arahan maksud dari tujuan adanya kegiatan pengabdian masyarakat yang dilakukan di Universitas PGRI Palembang. Selanjutnya dosen secara bergiliran memberikan materi sesuai dengan temanya masing-masing.

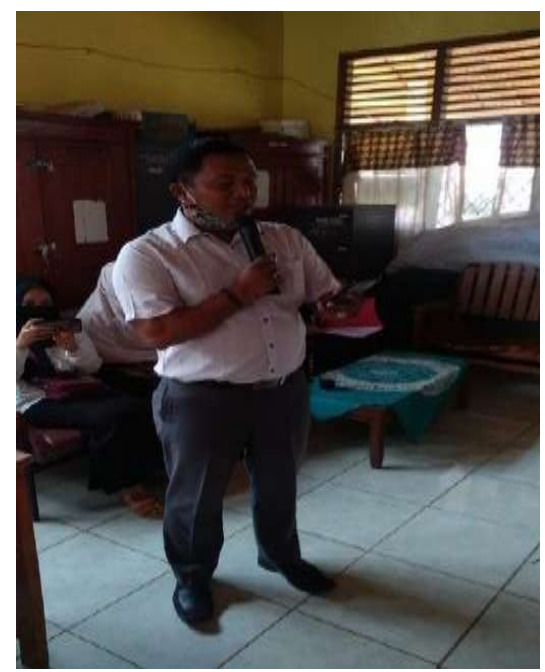

Gambar 1. Penyampaian Materi

Materi pertama diawali dengan penjelasan tentang apa itu Pengembangan Sumber Daya Manusia pada Koperasi. Materi ke dua dilanjutkan dengan bagaimana bentuk Manajemen Koperasi. Materi ke tiga menjelaskan tentang Kinerja Keuangan Koperasi. Materi ke empat menjelaskan tentang Pengembangan Usaha Koperasi, dan materi ke lima menjelaskan tentang Pengaruh Usaha Koperasi. Setelah masing dosen mmberikan penjelasan, diberikan kesempatan untuk guru dan siswa mengajukan beberapa pertanyaan 


\section{W/AHANA DEDIKASI}

berkenaan dengan koperasi sekolah, cukup besar animo atau tanggapan dari beberapa tanggapan yang disampaikan

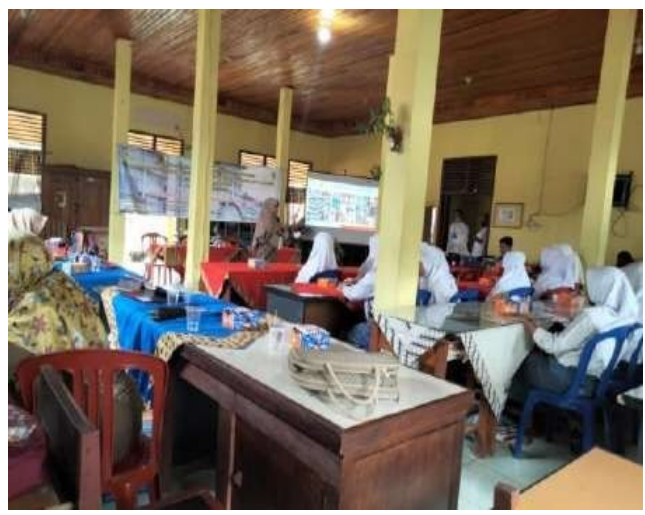

Gambar 2. Sesi Tanya Jawab Siswa

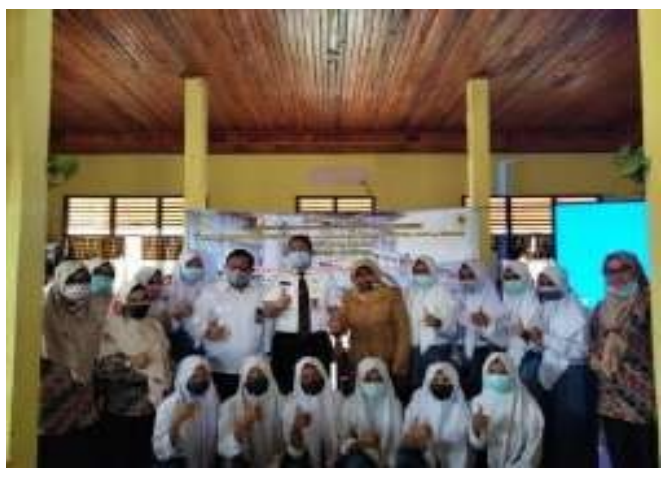

Gambar 3. Foto Bersama Siswa

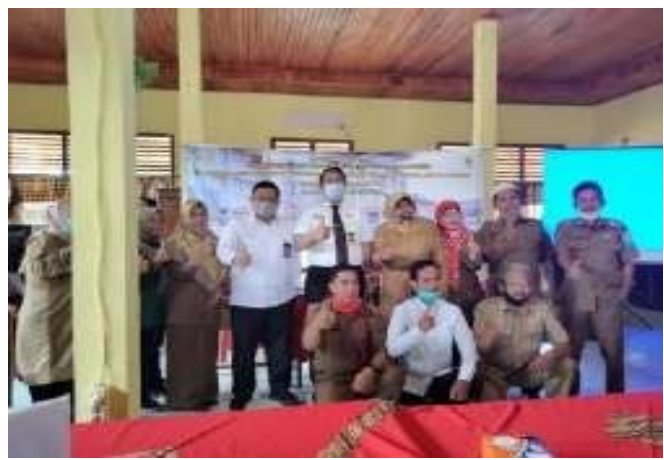

Gambar 4. Foto Bersama Dewan Guru

\section{KESIMPULAN}

Telah terlaksana dengan baik dan selesai sebagaimana waktu yang telah ditentukan. Rangkaian acara kegiatan ini dimulai dari salah satu dosen melakukan pembukaan dan pengantar serta arahan maksud dari tujuan adanya kegiatan pengabdian masyarakat yang dilakukan di Universitas PGRI Palembang. Selanjutnya dosen secara bergiliran memberikan materi sesuai dengan temanya masing-masing. Dengan adanya pemberian materi kepada siswa semoga dapat diterapkan dikehidupan mereka baik saat ini maupun nanti setelah lulus sekolah.

\section{DAFTAR PUSTAKA}

Anita, E. (2014). Pendidikan Kewirausahaan. [online] tersedia:

http://assetanita.blogspot.com/2 014/12/pendidikankewirausahaan.html Apriyanto, M., Oklianda, A., Putra, D. D., \& Warmi, A. (2021, February). Student Responses During Online Learning in the Covid-19 Pandemic Period. In Journal of Physics: Conference Series (Vol. 1764, 


\section{W/AHANA DEDIKASI}

No. 1, p. 012125). IOP Publishing.

Danuhadimedjo, Djatmiko. (2010). Kewirausahaan dan

Pembangunan. Bandung:

Alfabeta

Hamalik, Oemar. (2007). Dasar-dasar Pengembangan Kurikulum. Bandung : PT. Remaja Rosdakarya

Keputusan Bersama Menteri

Pendidikan Dan Kebudayaan, Menteri Agama, Menteri Kesehatan, Dan Menteri Dalam Negeri Republik Indonesia. (2020). Diakses pada : 26 Nov 2020 melalui : SKB 4 Menteri Pembelajaran 2020 Covid19.pdf

Keputusan Menteri Kesehatan

Republik Indonesia. (2020).

Diakses pada : 26 Nov 2020 melalui : files $80007 \mathrm{KMK}$ No. HK.01.07-MENKES-3282020 ttg Panduan Pencegahan Pengendalian COVID-19 di Perkantoran dan Industri.pdf Mulyasa, E. Implementasi Kurikulum Tingkat Satuan Pendidikan. (2013). Jakarta:Bumi Aksara

Putra, D. D., Okilanda, A., Arisman, A., Lanos, M. E. C., Putri, S. A. R., Fajar, M., ... \& Wanto, S. (2020). KUPAS TUNTAS PENELITIAN

PENGEMBANGAN MODEL
BORG \& GALL. Wahana Dedikasi: Jurnal PkM Ilmu Kependidikan, 3(1), 46-55. Suherman, Eman. (2013). Desain Pembelajaran Kewirausahaan, Bandung: Alfabeta https://pengajar.co.id/kewirausa haan-adalah/ 26 Oktober 2020, pukul 11.00 WIB 